\title{
Public Discovery of the Concept of Time Value of Money with Economic Value of Time
}

\author{
Iskandar Muda
}

Accounting Department, Faculty of Economics and Business, Universitas

Sumatera Utara, Medan, Indonesia

\author{
Abdul Nasser Hasibuan \\ Accounting Department, Faculty of Economics and Business, Institut Agama Islam \\ Negeri, Padang Sidempuan, Indonesia
}

\begin{abstract}
Purpose - The purpose of this research is to know the public discovery of the concept of time value of money with economic value of time.

Design/Methodology/Approach - The method of research involved a causal research design in North Sumatera Province, Indonesia. The data used are primary data sourced from questionnaires distributed to 112 random respondents. Data were analyzed using the SEM method with Smart PLS software.

Findings - The results show that the public do not know exactly the application and the concept of "time value of money" and the economic value of time.

Research Limitations/Implications - The limitation of this study is that it was conducted on heterogeneous Medan city samples and did not extend to other cities in North Sumatra with large samples. The study has implications on the socialization of the community's understanding of the concept of time value of money with the economic value of time.

Originality/Value - This study has value in that it compares the understanding of the society over the concept model of time value of money and the economic value of time.
\end{abstract}

Keywords Time value of money, economic value of time, coal, Public discovery

All papers within this proceedings volume have been peer reviewed by the scientific committee of the Malikussaleh International Conference on Multidisciplinary Studies (MICoMS 2017).

\section{Introduction}

The concept of time value of money is needed by financial managers for making decisions on when to invest in an asset and when to determine the source of loan funds to be allocated. If a certain amount of money will be received at a future time, in the present value, then the amount of money should be discounted with a certain interest rate (Zaman and Movassaghi, 2002; Thomi, 2014). If a certain amount of money is currently in value for the future, then the amount of money must be multiplied by a certain interest rate. Limitations that will lead to

(C) Iskandar Muda and Abdul Nasser Hasibuan. Published in the Emerald Reach Proceedings Series. Published by Emerald Publishing Limited. This article is published under the Creative Commons Attribution (CC BY 4.0) licence. Anyone may reproduce, distribute, translate and create derivative works of this article (for both commercial and non-commercial purposes), subject to full attribution to the original publication and authors. The full terms of this licence may be seen at http:// creativecommons.org/licences/by/4.0/legalcode

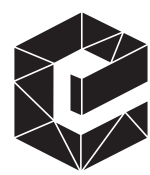

Emerald Reach Proceedings Series Vol. 1 
the public only save money if (for) apbila high bank interest rates, because they assume that if the bank's interest is high, then the money they will receive in the future is also high (Syahyunan et al., 2017). The time value of money does not take into account the inflation rate. The question of whether there is any time value of money in Islam has always been asked by many parties - from experts to practitioners. Although the answer to this question will illustrate how the attitude of Islamic economics determine the parameters of investment decisions (Qureshi, 2013), the answer would be one of the benchmarks in differentiating Islamic economics with today's modern economy, especially in the financial sector. Time value of money basically represents a person's time preference in holding money. Based on this theory, an economic actor is assumed to be more inclined to hold current money than the future. According to conventional assumptions that human preference is only driven by human nature, there is nothing wrong in the theory of time value of money. The only question is whether Islamic economics follows the same concept on this issue. In Islamic economic theory, it must be admitted that man has an inherent need according to the traits existing in him. However, to meet that need, he is not free to do anything he wants because he is limited by the law (sharia) and the values (aqeedah) and morals he believes. In this paper, we discuss this theory on the basis of this philosophy and on the assumptions underlying why the time value of money exists (Akacem and and Gillian, 2002; El-Ansary, 2005; Babikir, 2006; Campante and Drott, 2015; Khoir, 2016). Therefore, we will discuss it through the theory of economic behavior because it may be that the time value of money differs from the Islamic perspective not solely on the field of application but on the basic assumption of economic behavior. With regard to wealth, in Islamic economics, the crucial question is essentially not "how" or "when" (Khan and Mirakhor, 1989; Haron and Ahmad, 2000; Huda et al., 2008; Karim, 2014), but more important is the question "for what." The economic value of time is a concept whereby time has an economic value, but money does not have a time value. The economic value of time can be interpreted to maximize the economic value of a fund at a periodic time. The basic calculation on the principle of timebased value of money is interest, while the basic calculation of the principle based on the economic value of time is ratio. The first question is how and when, assuming that all human beings have the same preference, is man consistent with the principle or the economic rationality (Mukhtar et al., 2014). In Islamic economics, there is no assumption that some money will provide fixed income because it does not have a fixed pre-determined return concept possessed by conventional finance through an interest-based economy. With the concept of assuring the profit of a certain amount of money, one would be more inclined to hold the present money than later, for there is a definite advantage that he can get from holding that money now. Or if he holds the money, then there must be a compensation for the profit he should get.

\section{Methods}

This type of research is a comparative study, which is conducted to compare the similarities and differences between two or more facts and the properties of the object in detail based on a particular frame of mind. In this study, the variables are self-sufficient but further study is needed for more than one sample or at different times (Achmad and Muda, 2017; Badaruddin et al., 2017; Nurlina and Muda, 2017; Sirojuzilam and Muda, 2017; Hasan et al., 2017; Honggowati et al., 2017; Muda et al., 2018). A total of 112 respondents were randomly selected for this research for understanding the concept of the time value of money with the economic value of time (Khoir, 2016). The indicators of the questions include rationality, falah in the world and the hereafter, the concept of need, and orientation of the balance between consumers and producers. 


\section{Result and discussion}

\subsection{Results}

3.1.1. Evaluation of the structural model (Inner model). Inner model evaluation through the bootstrapping menu also generates $T$-statistics values that will be used to test the hypothesis. The criteria are $T$-statistic $>1.66$ (Dalimunthe and Muda, 2017; Ferine et al., 2017; Sirojuzilam and Muda, 2017). If the value of $t_{\text {count }}<t$ table, then $H_{0}$ is accepted and when the value of $t_{\text {count }}>t_{\text {table }}$ then $H_{0}$ is rejected, which means that for the variable in question there is a significant influence (Lutfi et al., 2016; Ferine et al., 2017; Lubis et al., 2017; Marhayanie et al., 2017; Muda, 2017; Sihombing et al., 2017). This means that the independent variables tested have a significant effect on the dependent variable. The result of the $T$-statistics value in the path coefficients of the table is presented in Figure 1.

The test effect can be seen in Table 1.

If Table 1 provides a coefficient of 0.005 , smaller than $1 \alpha=5 \%$, then the decision of the hypothesis testing is to reject $H_{0}$ and accept the hypothesis $H_{\mathrm{a}}$ (Asmeri et al., 2017; Hanggowati et al., 2017; Jones et al., 2017; Khoiruman and Haryanto, 2017; Muda et al., 2017; Rahmawati et al., 2017; Suprianto et al., 2017). The results show that the economic value of time is a significant variable on the application and the concept model $(Y)$. In addition to testing the hypothesis through the bootstrapping menu, which produces $T$-statistics, inner

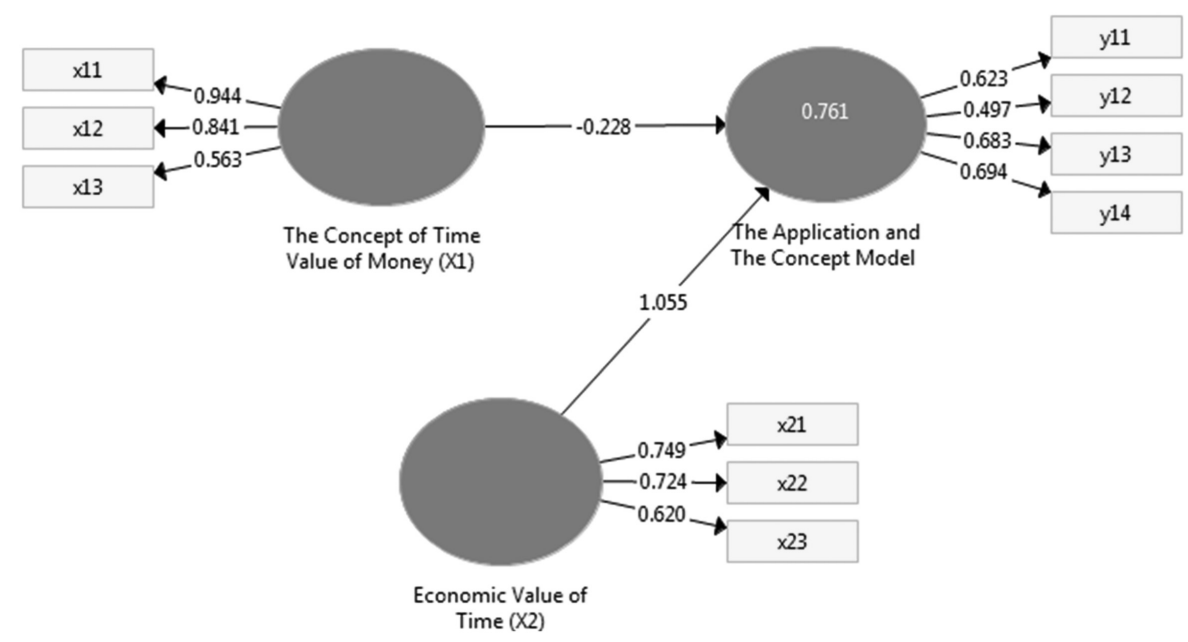

Figure 1.

Overall Model with Coefficient

\begin{tabular}{|c|c|c|c|c|c|c|}
\hline & $\begin{array}{l}\text { Original } \\
\text { Sample }\end{array}$ & $\begin{array}{c}\text { Sample } \\
\text { Mean }\end{array}$ & $\begin{array}{l}\text { Standard } \\
\text { Deviation }\end{array}$ & $\begin{array}{c}T \\
\text { Statistics }\end{array}$ & $\begin{array}{c}P \\
\text { Values }\end{array}$ & \\
\hline $\begin{array}{l}\text { Economic value of time }(X 2)->\text { the } \\
\text { application the concept model }\end{array}$ & 0.522 & 0.508 & 0.119 & 4.379 & 0.000 & Table 1 \\
\hline $\begin{array}{l}\text { The concept of time value of money the -> } \\
\text { the appltheion and the concept model }\end{array}$ & 0.171 & 0.185 & 0.106 & 1.614 & 0.107 & $\begin{array}{l}\text { The Result of } \\
\text { Bootstrapping }\end{array}$ \\
\hline
\end{tabular}




\section{Proceedings of}

MICoMS 2017

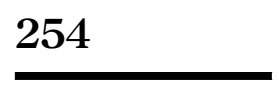

Figure 2.

$F^{2}$ Value

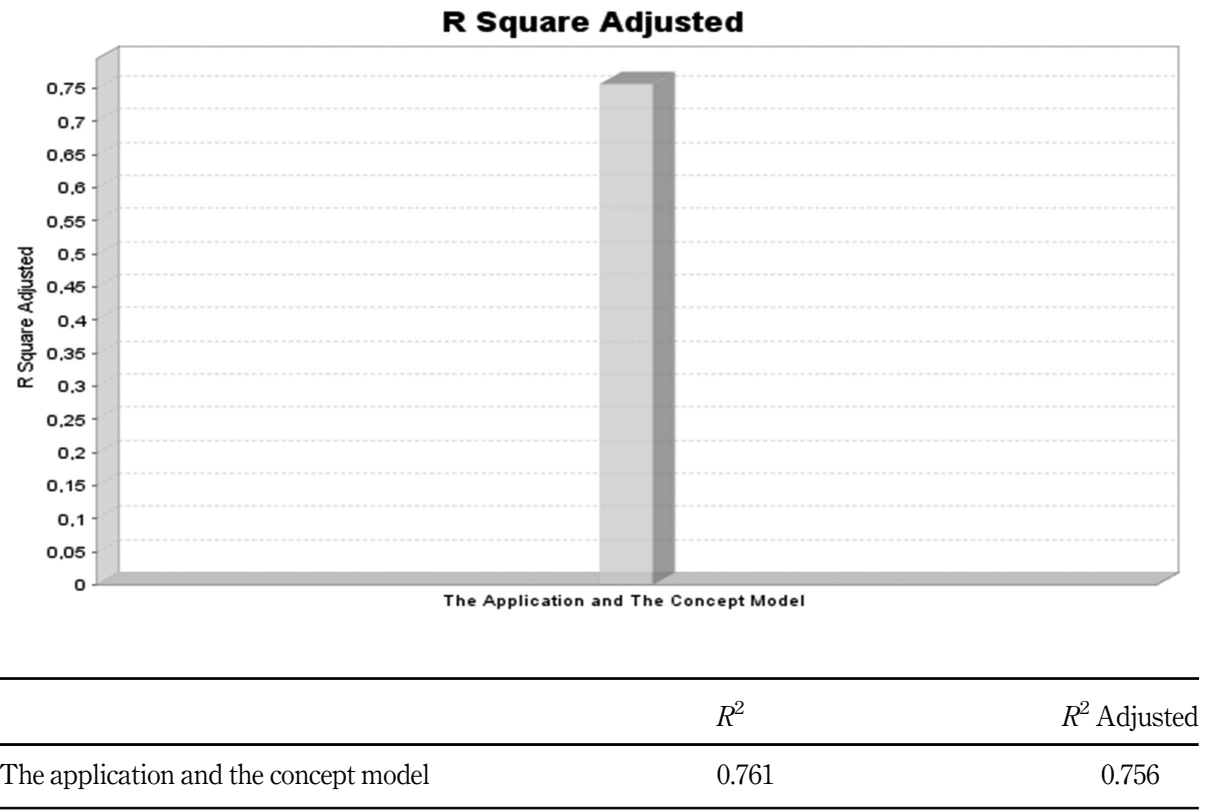

Table 2.

$R^{2}$ Value

model evaluation is also done by reviewing the $R^{2}$ value (Muda, 2017). The $R^{2}$ value generated from the inner model evaluation is presented in Table 2 and Figure 2.

The variation of the $R^{2}$ value is $75.6 \%$. The economic value of time is a significant variable on the application and the concept model $(Y)$.

\subsection{Discussion}

Islamic economic perspectives are not familiar with the method of time value of money because this method adds value to money solely with increasing time and not the effort that it actually leads to Ribawi transactions as the opinion of Imam Nawawi provides definitions related to the addition of value of money which is based only on time value is the category of usury. Islam actually knows the money value of time, that is, time has an economic value. In accordance with Islamic teachings, efficient and fair monetary management is not based on the application of the method of interest. Redeeming the decline in the value of money due to eroded inflation and consumption of time is to make money productive and/or recover the yield that exceeds the rate of inflation. The most effective way is to invest the funds in order to generate returns above the inflation rate so that the value of the existing money is relatively fixed or can even increase.

\section{Limitation and implications}

The limitation of this study is that it was conducted on heterogeneous Medan city samples and did not extend to other cities in North Sumatra with larger sample sizes. The study has 
implications on the socialization of the community's understanding of the concept of time value of money with the economic value of time.

\section{Conclusions}

The results show that the public do not know exactly the application and the concept model of the time value of money and the economic value of time.

\section{References}

Achmad, N. and Muda, I. (2017). "Economic Activities of Karo Older Adults in Lingga Village, Tanah Karo Regency, North Sumatera, Indonesia”. International Journal of Economic Research, Vol. 14, No. 16, pp. 365-379.

Akacem, M. and Gillian, L. (2002). "Principles of Islamic Banking: Debt Versus Equity Financing”, Middle East Policy, Vol. 9, No. 1, pp. 127-131.

Asmeri, R., Alvionita, T. and Gunardi, A. (2017). "CSR Disclosures in the Mining Industry: Empirical Evidence from Listed Mining Firms in Indonesia". Indonesian Journal of Sustainability Accounting and Management, Vol. 1, No. 1, pp. 16-22. Doi: 10.28992/ijsam.v1i1.23.

Babikir, A.O. (2006). "Islamic Banking in Practice". In Paper presented in International Course on Principles and Practices of Islamic Economics and Banking, Baku, Azerbaijan.

Badaruddin, R., Ermansyah, E. and Muda, I. (2017). "Village Governance with Implementation of Law Number 6 of 2014 on the Village and Village Administration". International Journal of Economic Research, Vol. 14, No. 16, pp. 350-363.

Campante, F. and Drott, D.Y. (2015). "Does Religion Affect Economic Growth and Happiness? Evidence from Ramadan”. The Quarterly Journal of Economics, Vol. 130, No. 2, pp. 615-658.

Dalimunthe, D.M.J. and Muda, I. (2017). "The Empirical Effect of Education and Training to the Performance of Employees". International Journal of Applied Business and Economic Research, Vol. 15, No. 24, pp. 5423-5437.

El-Ansary, W. (2005). "The Quantum Enigma and Islamic Sciences of Nature: Implications for Islamic Economic Theory". In Paper presented at the 6th International Conference on Islamic Economics, Jeddah.

Ferine, F.K., Ermiaty, C. and Muda, I. (2017). "The Impact of Entrepreneurship and Competence on Small Medium Enterprises Tangan Di Atas (TDA) Medan Entrepreneurs' Work Performance". International Journal of Economic Research, Vol. 14, No. 16, pp. 380-393.

Haron, S. and Ahmad, N. (2000). "The Effects of Conventional Interest Rates and Rate of Profit on Funds Deposited with Islamic Banking System in Malaysia”. International Journal of Islamic Financial Services, Vol. 1, No. 4, pp. 89-107.

Hasan, A., Gusnardi and Muda, I. (2017). "Analysis of Taxpayers and Understanding Awareness Increase in Compliance With Taxpayers Individual Taxpayers". International Journal of Economic Research, Vol. 14, No. 12, pp. 75-90.

Honggowati, S., Rahmawati, R., Aryani, Y.A. and Probohudono, A.N. (2017). "Corporate Governance and Strategic Management Accounting Disclosure". Indonesian Journal of Sustainability Accounting and Management, Vol. 1, No. 1, pp. 23-30. Doi: 10.28992/ijsam.v1i1.24.

Huda, N., Nasution, M.E., Risza, I.H. and Ranti, W. (2008). Macroeconomic Economics Theoretical Approach. Kencana Publishers, Jakarta.

Jones, P., Wynn, M., Hillier, D. and Comfort, D. (2017). "The Sustainable Development Goals and Information and Communication Technologies". Indonesian Journal of Sustainability Accounting and Management, Vol. 1, No. 1, pp. 1-15. DOI: 10.28992/ijsam.v1i1.22.

Karim, A.A. (2014). Macroeconomic Economics (3rd ed.). PT RajaGrafindo Persada Publishers, Jakarta. 
Proceedings of Khan, M.S. and Mirakhor, A. (1989). "The Financial System and Monetary Policy in an Islamic MICoMS 2017 Economy”. Journal of King Abdul Aziz University: Islamic Economics, Vol. 1, No. 1, pp. 39-57.

Khoir, M. (2016). “Time Rate of Money in Islamic Economic Perspective”. Journal of Sharia Economics, Vol. 42, No. 2, pp. 71-84.

Khoiruman, M. and Haryanto, A.T. (2017). "Green Purchasing Behavior Analysis of Government Policy About Paid Plastic Bags". Indonesian Journal of Sustainability Accounting and Management, Vol. 1, No. 1, pp. 31-39. DOI: 10.28992/ijsam.v1i1.25.

Lubis, A., Rustam and Muda, I. (2017). "Factors Affecting the Cost of Agency of Village Owned Enterprise (BUMDES) in Indonesia”. International Journal of Economic Research, Vol. 14, No. 16, pp. 334-348.

Lutfi, M., Nazwar, C. and Muda, I. (2016). "Effects of Investment Opportunity Set, Company Size and Real Activity Manipulation of Issuers in Indonesia Stock Exchange on Stock Price in Indonesia”. International Journal of Economic Research, Vol. 13, No. 5, pp. 2149-2161.

Marhayanie, Ismail, M. and Muda, I. (2017). "Impact of the Online Car Rental Service Order System on Sales Turnover with Financial Literacy Customer as Intervening Variables". International Journal of Economic Perspectives, Vol. 14, No. 16, pp. 317-332.

Muda, I., Dharsuky, A., Siregar, H.S. and Sadalia, I. (2017). "Combined Loading and Cross-Dimensional Loadings Timeliness of Presentation of Financial Statements of Local Government". IOP Conference Series: Materials Science and Engineering, Vol. 180, pp.1-5. DOI: 10.1088/1757-899X/ 180/1/012099.

Muda, I., Rahmanta, S.A. and Marhayanie. (2017). "The Role of Working Capital, Productivity, Applied Technology and Selling Market Prices on Fisherman's Revenues". International Journal of Economic Research, Vol. 14, No. 16, pp. 291-302.

Muda, I., Weldi, M., Siregar, H.S. and Indra, N. (2018). "The Analysis of Effects of Good Corporate Governance on Earnings Management in Indonesia with Panel Data Approach". Iranian Economic Review, Vol. 22, No. 2, pp. 657-669.

Muda, I. (2017). "The Effect of Allocation of Dividend of the Regional Government-Owned Enterprises and the Empowerment Efforts on the Revenue of Regional Government: The Case of Indonesia". European Research Studies Journal, Vol. XX, No. 3A, pp. 223-246.

Mukhtar, M.M., Nihal, H.M.S., Rauf, H.A., Wasti, W. and Qureshi, M.S. (2014). "Socio-Economic Philosophy of Conventional and Islamic Economics: Articulating Hayat-e-Tayyaba Index (HTI) on the Basis of Maqāsid al-Sharīah”. Islamic Economic Studies, Vol. 22, No. 2, pp. 65-98.

Nurlina and Muda, I. (2017). "The Analysis of the Effects of Capital Expenditure and Human Development Index on Economic Growth and Poverty in East Aceh Regency". International Journal of Economic Research, Vol. 14, No. 16, pp. 395-409.

Qureshi, M.S. (2013). "Entrepreneurship plus: The Impact of Spiritual Orientation on Entrepreneurial Orientation, Market Orientation and the Entrepreneurial Process".. In Paper Presented at the International Research Conference on Contemporary Management Practices, Lahore School of Economics, Lahore, Pakistan.

Rahmawati, R., Rispantyo, R. and Djamaluddin, S. (2017). "Mentoring Function and Quality of Supervisor Auditor Relationship: Organizational Justice as a Mediation. Indonesian Journal of Sustainability Accounting and Management, Vol. 1, No. 1, pp. 40-48. DOI: 10.28992/ijsam. v1i1.26.

Sihombing, M., Muda, I., Jumilawati, E. and Dharsuky, A. (2017). "Factors Affecting the Success of Local Innovation Systems with Government Programs as Moderators". International Journal of Economic Research, Vol. 14, No. 16, pp. 272-289.

Sirojuzilam, H.S. and Muda, I. (2017). "Effect of Private Collaborative as a Moderation of Success of Agropolitan Program. International Journal of Economic Research, Vol. 14, No. 16, pp. 304-315. 
Suprianto, E., Suwarno, S., Murtini, H., Rahmawati, R. and Sawitri, D. (2017). "Audit Committee Accounting Expert and Earnings Management with "Status" Audit Committee as Moderating Variable". Indonesian Journal of Sustainability Accounting and Management, Vol. 1, No. 2, pp. 49-58. DOI: 10.28992/ijsam.v1i2.16.

Syahyunan, Muda, I., Siregar, H.S., Sadalia, I. and Chandra, G. (2017). "The Effect of Learner Index and Income Diversification on the General Bank Stability in Indonesia". Banks and Bank Systems, Vol. 12, No. 4, pp. 56-64. DOI: http://10.21511/bbs.12(4).2017.05.

Thomi, D.K. (2014). The Effect of Islamic Banking Products on Financial Performance of Commercial Banks in Kenya. The Degree of Master of Business Administration. The University of Nairobi.

Zaman, M.R. and Movassaghi, H. (2002). "Interest-Free Islamic Banking: Ideals and Reality. The International Journal of Finance, Vol. 14, No. 4, pp. 2428-2443.

\section{Corresponding author}

Iskandar Muda can be contacted at iskandar1@usu.ac.id 